\title{
EVALUASI DAN REDESIGN WEBSITE PENDIDIKAN TINGGI DENGAN MENERAPKAN USER EXPERIENCE LIFECYCLE
}

\author{
M. Gilvy Langgawan Putra*1, Michael Renaldi ${ }^{2}$, Sri Rahayu Natasia ${ }^{3}$ \\ 1,2,3 Program Studi Sistem Informasi, Institut Teknologi Kalimantan \\ Email: ${ }^{1}$ gilvy.langgawan@lecturer.itk.ac.id, ${ }^{2} 10151023 @$ student.itk.ac.id, ${ }^{3}$ natasia.ayu @ lecturer.itk.ac.id \\ *Penulis Korespondensi
}

(Naskah masuk: 17 November 2020, diterima untuk diterbitkan: 24 Maret 2021)

\begin{abstract}
Abstrak
Pada awalnya perguruan tinggi membuat situs web untuk mengenalkan dan mempromosikan lembaga pendidikannya. Diresmikannya Undang-Undang Nomor 14 Tahun 2008 tentang Keterbukaan Informasi Publik (UU KIP) dan Undang-Undang Nomor 25 Tahun 2009 tentang Pelayanan Publik (UU PP) menciptakan suatu keputusan di mana badan publik wajib "meningkatkan pengelolaan dan pelayanan informasi di lingkungan badan publik untuk menghasilkan layanan informasi yang berkualitas". Penelitian yang bertujuan untuk meningkatkan kualitas situs web ITK dan mengecilkan tanggapan kurang baik yang diberikan mahasiswa ITK dilakukan dengan cara melakukan evaluasi dan redesign pada situs web ITK guna memperbaiki kualitas situs web ITK dan juga untuk mengurangi permasalahan yang di alami pengguna situs web ITK. Digunakan metode User Experience Lifecycle Template pada penelitian ini dikarenakan metode ini dapat digunakan untuk mengembangkan suatu produk (Prototype, Hardware, dan Software). Adapun hasil yang didapat pada penelitian kali ini ialah, pada aspek learnability meningkat $2 \mathrm{x}$ lebih cepat dibandingkan situs web ITK yang lama, lalu pada aspek efficiency didapat persentase pengguna mencapai tujuannya dalam menggunakan situs web ITK yang baru sebesar $94.40 \%$, lalu pada aspek memorability jumlah klik mengalami penurunan pada situs web ITK yang baru jika dibandingkan dengan web ITK yang lama, dan pada aspek eror yang akan terjadi pada situs web ITK yang baru bernilai $1.61 \%$ kemungkinan.
\end{abstract}

Kata kunci: evaluation, ITK, user experience lifecycle template, situs web

\section{EVALUATION AND REDESIGN THE HIGHER EDUCATION WEBSITE BY APPLYING USER EXPERIENCE LIFECYCLE}

\begin{abstract}
At first, the college created a website to introduce and promote its educational institutions. The establishment of Law No. 14 the year 2008 on Public Information Disclosure (KIP Law) and Law No. 25 of 2009 on public services (ACT PP) creates a decision where public bodies are obliged to "improve the management and information services in the public agency to produce quality information services". The research aimed at improving the quality of the ITK website and discouraging the poor responses given by ITK students are conducted by evaluating and redesign the ITK website to improve the quality of ITK's website and also to reduce the problems that are in the user's natural ITK website. Used method User Experience Lifecycle Template in this research because this method can be used to develop a product (Prototype, Hardware, and Software). As for the results gained on the research this time is, on the aspects of learnability increased $2 x$ faster than the old ITK website, then on the efficiency aspect gained the percentage of users reached its goal in using the new ITK website $94.40 \%$, then on the memorability aspect of the number of clicks decreased on the new ITK website when compared to the old web ITK, and on the aspect of the error that will happen to the new ITK Web site worth $1.61 \%$ of the probability.
\end{abstract}

Keywords: evaluation, ITK, user experience lifecycle template, website

\section{PENDAHULUAN}

Pengalaman pengguna dapat menjadi tolok ukur penerimaan terhadap sebuah situs web. Jika seorang pengguna mengalami kesusahan dan tidak nyaman dalam menggunakan sebuah layanan aplikasi, atau layanan aplikasi tersebut sulit untuk digunakan, maka layanan aplikasi tersebut memiliki potensi kegagalan. Pendekatan melalui aspek usability dapat digunakan 
dalam menganalisis user experience pada suatu aplikasi berbasis situs web (Sulistiyono, 2017).

Sejak di publikasikannya situs web Institut Teknologi Kalimantan (ITK) pada tahun 2016 hingga awal tahun 2020, situs web ITK belum pernah dilakukan penilaian kualitas situs web. Melihat belum pernah dilakukannya pelaksanaan penilaian kualitas situs web ITK, maka dilakukan pengambilan data pengalaman pengguna situs web ITK kepada mahasiswa ITK dari angkatan 2016 hingga 2019 dengan menggunakan kuesioner untuk mengetahui kualitas pengalaman pengguna situs web milik ITK.

Berdasarkan hasil pengambilan data kepada mahasiswa ITK, didapatkan balasan sebanyak 430 data terkait kualitas situs web ITK dengan hasil kesimpulan sebagai berikut:

1. Banyak mahasiswa ITK yang mengatakan tampilan pada situs web ITK perlu diperbaiki karena terlalu sederhana, terutama pada tampilan mobile browser yang kurang responsive.

2. Banyak mahasiswa ITK yang mengatakan jika informasi yang ada pada situs web ITK kurang lengkap dan banyak yang belum di perbaharui.

3. Banyak mahasiswa ITK yang mengatakan struktur situs web ITK yang membingungkan ketika pengguna baru menggunakan situs web.

Oleh karena alasan tersebut, perlu dilakukannya evaluasi dan redesign pada website ITK. Dilakukannya evaluasi dan redesign website ITK ini bertujuan agar terjadi peningkatan aspek usability website. Menurut (Yumarlin, 2016), salah satu metode yang dapat digunakan dalam menilai kualitas situs web adalah usability testing. Merujuk kepada judul penelitian, adapun metode yang akan digunakan pada penelitian kali ini tidak hanya berupa metode usability test saja yang berfungsi untuk mengukur tingkat learnability, Efficiency, Memorability, Errors, dan Satisfaction pada situs web ITK, namun terdapat juga metode User Experience Lifecycle Template yang digunakan sebagai metode penelitian utama pada Evaluasi Dan Redesign Website Institut Teknologi Kalimantan yang melingkupi tahapan analisa, desain, implementasi, dan evaluasi.

User Experience Lifecycle Template merupakan sebuah kerangka kerja yang dapat diterapkan ketika ingin mengembangkan suatu produk (Prototype, Hardware, dan software) (Rex \& Pardha, 2012). Terdapat empat tahapan dalam metode ini yang di antaranya adalah Analyze, Design, Implement, dan Evaluation, dalam pengimplementasiannya metode usability testing tadi akan masuk ke dalam tahapan evaluation yang terdapat pada metode User Experience Lifecycle Template ini.

Dengan adanya permasalahan yang telah temukan tadi dan ditemukan juga metode yang dapat digunakan untuk menyelesaikan permasalahan tersebut, maka perlu dilakukan uji coba metode pada Evaluasi Dan Redesign Website Institut Teknologi Kalimantan untuk mengetahui tingkat keberhasilan dalam meningkatkan kualitas pada situs web ITK dalam segi usability dan informasi.

\section{METODE PENELITIAN}

Metode penelitian ini merupakan adaptasi dari User Experience Lifecycle Template. Adapun metode penelitian yang digunakan pada penelitian ini dapat dilihat pada Gambar 1.

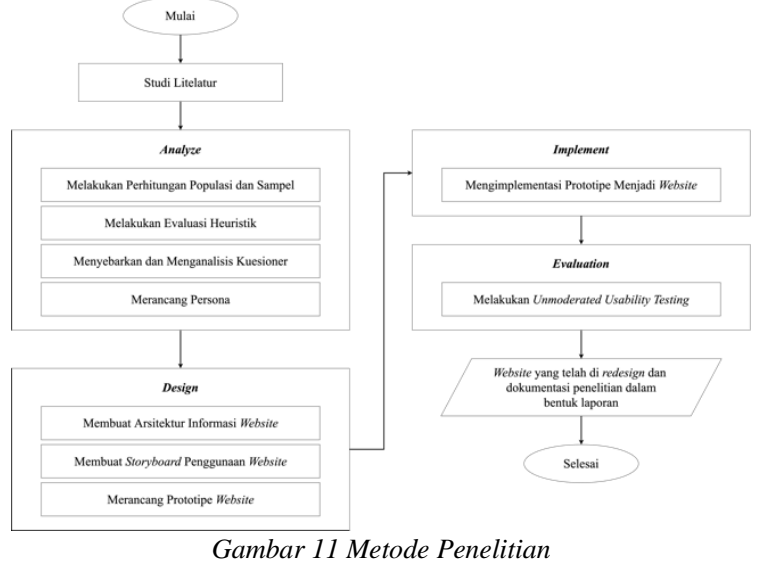

Tahapan dimulai dengan melakukan Studi Litelatur terkait metode yang akan digunakan data yang akan diambil. Selanjutnya dilakukan tahap Analyze yang terdapat empat tahapan yaitu melakukan perhitungan sampel dan populasi dengan menggunakan tabel perhitungan sampel Isaac dan Michael yang di mana hasilnya akan dijadikan acuan dalam melakukan penyebaran kuesioner evaluasi situs web ITK, setelah itu dilakukan heuristic evaluation dengan metode yang di anut dari Nielsen untuk mendapatkan data kelebihan dan kekurangan pada situs web ITK, setelah itu dilakukan penyebaran dan analisis kuesioner yang di mana penyebarannya akan dilakukan dengan metode kuesioner digital, setelah itu akan dilakukan perancangan persona dari data responden yang telah didapat. Tahap analisis telah selesai lanjut ke tahap Design yang di mana pada tahap ini akan dilakukan pembuatan arsitektur informasi situs web ITK yang hasilnya akan berupa sitemap, setelah itu dilakukan pembuatan storyboarding penggunaan situs web ITK yang hasilnya akan berupa tabel tata cara penyelesaian setiap tugas yang dapat dilakukan pada situs web, setelah itu akan dilakukan pengembangan rancangan desain dalam bentuk prototipe situs web. Tahap desain telah selesai lanjut ke tahap Implement yang di mana pada tahap ini akan di implementasikan hasil rancangan prototipe yang telah jadi ke dalam bentuk situs web yang dapat di akses. Tahap implementasi telah selesai lanjut ke tahap Evaluation yang di mana pada tahap ini akan dilakukan pengujian unmoderated usability test dengan 7 responden dengan hasil yang akan diperoleh adalah tabel data jumlah keberhasilan dalam mengerjakan tugas yang di uji, lalu tabel data durasi menyelesaikan tugas, dan tabel data jumlah klik dalam menyelesaikan tugas. Semua tahapan tadi akan menghasilkan keluaran 
dokumen laporan dan situs web yang telah di evaluasi dan di redesign.

\section{TINJAUAN PUSTAKA}

\subsection{User Experience Lifecycle Template}

User Experience Lifecycle Template merupakan sebuah kerangka kerja yang dapat diterapkan ketika ingin mengembangkan suatu produk (Prototype, Hardware, dan software) Terdapat empat tahapan dalam metode ini yang di antaranya adalah Analyze, Design, Implement, dan Evaluation (Rex \& Pardha, 2012) (Morville \& Rosenfeld, 2007)

\section{Analyze}

Analyze dilakukan untuk mendapatkan pemahaman bekerja pengguna dan mengetahui apa yang dibutuhkan. Penerapan analyze dalam penelitian ini dilakukan dengan cara menentukan target pengguna dari situs web ITK, setelah itu dilakukan perhitungan populasi dan sampel dari target pengguna, setelah itu dilakukan penyebaran kuesioner guna untuk mendapatkan data kebutuhan dari pengguna.

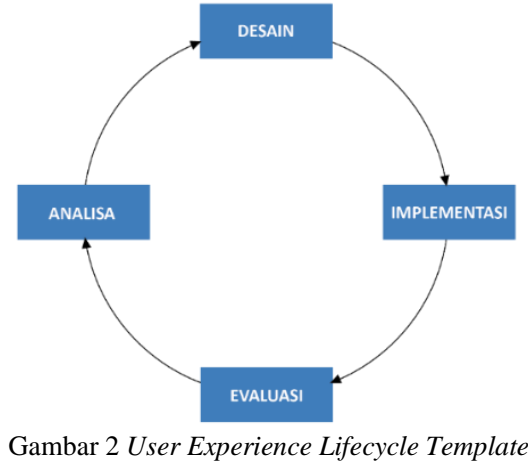

Hasil dari penyebaran kuesioner akan dianalisis, dikelompokkan, disortir, dan dikembangkan untuk membentuk data kebutuhan dan kesusahan pengguna dalam menggunakan situs web. Selain melakukan tahapan analisis data, pada tahap pertama ini juga akan dilakukan heuristic evaluation dengan capaian yang didapatkan adalah fungsi, halaman, dan bagian apa saja yang dapat membuat pengalaman pengguna menjadi buruk (Goodman, et al., 2012) (Nielsen, 1995) (Sugiyono, 2011).

\section{Design}

Design dilakukan bertujuan untuk membuat suatu konsep interaksi desain (Preece, et al., 2002). Pada tahap ini dilakukan perancangan sitemap yang dibuat menggunakan data yang didapatkan pada

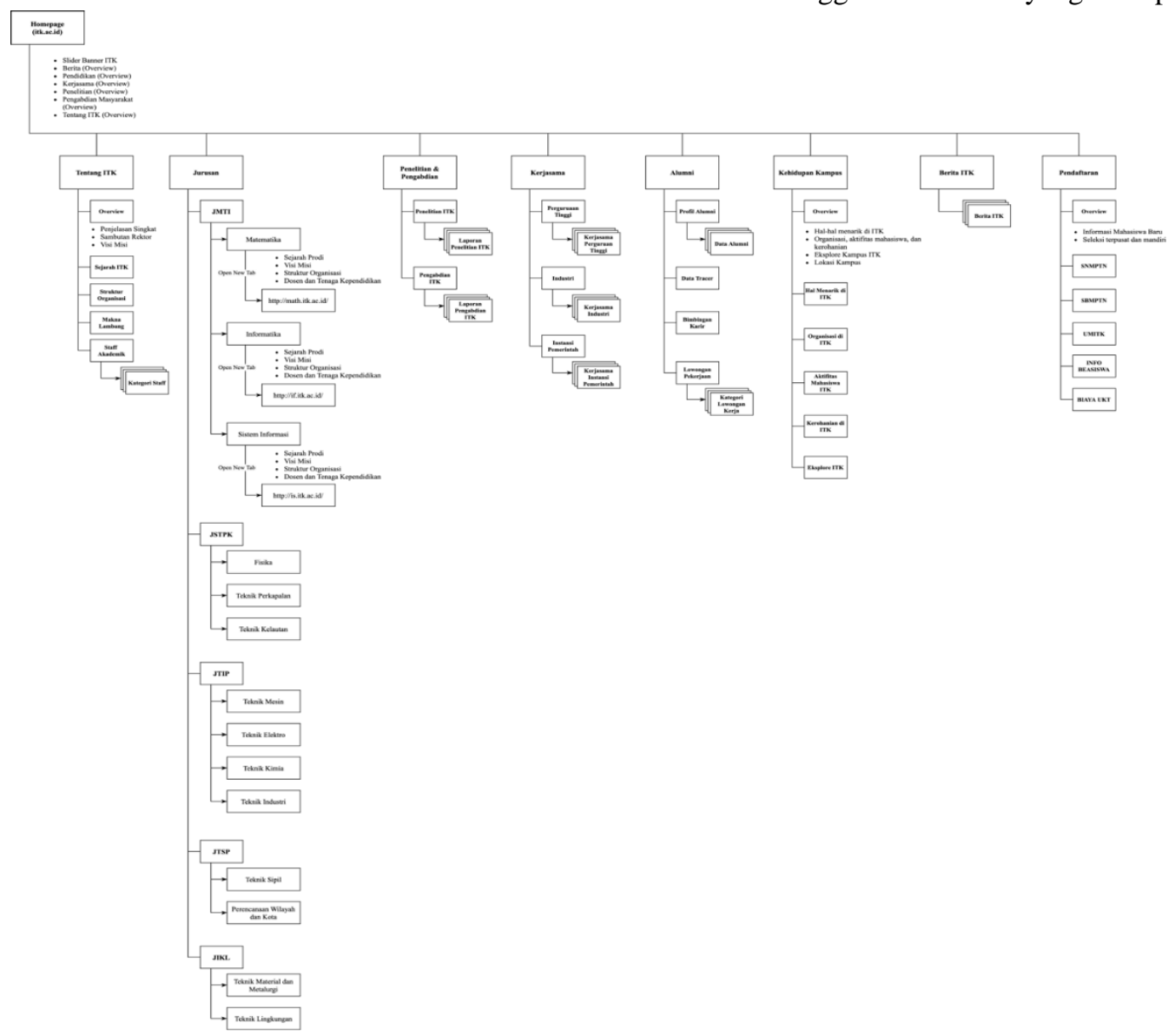


tahap analyze yaitu data user needs dan fuctional requirement. Setelah terbentuknya sitemap situs web maka perlu juga dibentuk alur situs web agar terbentuknya situs web yang mudah dipahami dan digunakan (Bank, 2014) (Morville \& Rosenfeld, 2007) (Tomlin, 2018).

\section{Implement}

Implement merupakan aktivitas ketiga pada UX Lifecycle, aktivitas ini berperan untuk mengembangkan atau mengimplementasikan hasil rancangan pada tahap-tahap sebelumnya menjadi produk jadi seperti software atau hardware, pada penelitian kali ini pengimplementasian yang dilakukan ke dalam bentuk situs web dengan menggunakan Content Management System (CMS), dan dalam pengimplementasiannya akan menggunakan plugin wordpress bernama Divi Builder (Arikunto, 2006) (Nasution, 2006).

\section{Evaluation}

Evaluation merupakan aktivitas keempat pada UX Lifecycle yang di mana penerapannya pada penelitian kali ini menggunakan metode unmoderated usability testing untuk melakukan pengujian dengan extream user, pengujian ini dilakukan dengan cara pengguna diberikan tugas untuk menyelesaikan suatu tahapan hingga selesai dan di rekam segala aktivitasnya selama pelaksanaan unmoderated usability testing untuk mengetahui durasi, jumlah kesalahan, dan tahapan pengguna menyelesaikan suatu tugas (Tomlin, 2018).

\subsection{Usability Testing}

Usability Testing merupakan aktivitas pengujian User Experience (UX) dan kegunaan suatu sistem atau aplikasi untuk membantu mengungkap mengapa permasalahan perilaku ini dianalisis pada langkah sebelumnya. Pelaksanaan usability testing dilakukan bersama partisipan yang sesuai dengan data persona penelitian, lalu partisipan tadi diberikan tugas atau skenario yang telah di tentukan dengan tujuan untuk mendapatkan data kualitatif terkait perilaku pengguna (Tomlin, 2018) (Nielsen, 1995).

Dalam menilai aspek learnability adapun persamaan yang digunakan untuk menilai aspek rasio Learnability ditunjukkan pada persamaan 1 (Pramono, et al., 2019).

rata - rata waktu pengujian web ITK lama rata - rata waktu pengujian web ITK baru

Dalam menilai aspek Efficiency adapun persamaan yang digunakan dalam menghitung aspek Efficiency ditunjukkan pada persamaan 2 (Pramono, et al., 2019).

$$
\text { Time Based Efficiency }=\frac{\sum_{J}^{R} \sum_{i=1}^{N} \frac{N i j}{t i j}}{N R} \times 100 \%
$$

Dalam menilai aspek Memorability adapun cara yang dilakukan yaitu mengamati jumlah klik dan jumlah langkah yang telah dilakukan oleh partisipan selama proses pengujian skenario berlangsung, lalu dibentuk ke dalam bentuk diagram garis perbandingan (Pramono, et al., 2019).

Dalam menilai aspek persentase Error adapun persamaan yang digunakan ditunjukkan pada persamaan 3 (Pramono, et al., 2019) (Polancik, 2009).

$$
\left(\frac{\text { jumlah langkah salah }}{\text { jumlah langkah benar }}\right) \times 100 \%
$$

\section{HASIL DAN PEMBAHASAN}

Hasil dari pengerjaan penelitian ini adalah membuat tabel rancangan perbaikan, architecture information situs web, implementasi rancangan desain ke dalam bentuk situs web, dan melakukan usability testing.

\section{A. Analyze}

Adapun hasil analisis permasalahan yang dimiliki situs web itk.ac.id yang didapat melalui heuristic evaluation, penyebaran kuesioner kepada target pengguna, dan wawancara kepada product owner di implementasikan ke dalam bentuk tabel perancangan perbaikan situs web pada Tabel 1 .

\begin{tabular}{|c|c|c|}
\hline RP-ID & Bagian yang di perbaiki & Mengacu Kepada \\
\hline RP-01 & $\begin{array}{l}\text { Navigasi menu memuat } \\
\text { (Beranda, Tentang ITK, } \\
\text { Jurusan, Penelitian \& } \\
\text { Pengabdian, Kerja Sama, } \\
\text { Alumni, Kehidupan } \\
\text { Kampus, Berita ITK, } \\
\text { Pendaftaran). }\end{array}$ & $\begin{array}{ll}- & \text { HE-1.5 } \\
- & \text { HE-5.3 } \\
\text { - } & \text { HE-7.3 } \\
\text { - } & \text { HE-10.1 } \\
- & \text { HE-10.2 } \\
- & \text { PO-01 }\end{array}$ \\
\hline RP-02 & $\begin{array}{l}\text { Perbaikan data website dan } \\
\text { informasi. }\end{array}$ & $\begin{array}{ll}\text { - } & \text { HE-1.4 } \\
\text { - } & \text { HE-2.1 } \\
\text { - } & \text { HE-9.1 } \\
\text { - } & \text { HE-9.5 } \\
\text { - } & \text { F-01 } \\
\text { - } & \text { F-02 } \\
\text { - } & \text { PO-02 }\end{array}$ \\
\hline RP-03 & $\begin{array}{l}\text { Semua aset gambar yang } \\
\text { akan di upload ke dalam } \\
\text { website dilakukan } \\
\text { compress terlebih dahulu. }\end{array}$ & - $\quad \mathrm{F}-03$ \\
\hline RP-04 & $\begin{array}{l}\text { Memperbaiki desain } \\
\text { responsive di setiap } \\
\text { halaman. }\end{array}$ & $\begin{array}{ll}- & \text { F-02 } \\
- & \text { F-04 } \\
\end{array}$ \\
\hline RP-05 & $\begin{array}{l}\text { Menyediakan fungsi live } \\
\text { chat pada website. }\end{array}$ & $\begin{array}{ll}\text { - } & \text { HE-3.1 } \\
\text { - } & \text { HE-10.3 }\end{array}$ \\
\hline
\end{tabular}

Tabel 1 Rencana Perbaikan Situs Web ITK

\section{B. Design}

Adapun hasil kebutuhan pengguna pada tahap Analyze dikembangkan menjadi bentuk architecture information, storyboard pengguna, dan prototipe situs web ITK untuk menjadi acuan dalam tahap implementasi selanjutnya. Berikut rancangan architecture information dari situs web itk.ac.id yang baru yang disajikan pada Gambar 3 .

\section{Implement}


Setelah dilakukan pembuatan tabel rancangan perbaikan, architecture information situs web itk.ac.id yang baru, langkah selanjutnya yakni mengimplementasi hasil rancangan prototipe ke dalam bentuk situs web.

1. Header, merupakan sebuah menu yang sering terdapat pada bagian atas sebuah situs web. Fungsi dari sebuah header adalah untuk menuntun pengguna dalam mencapai tujuannya. Adapun implementasi header pada situs web itk.ac.id dapat dilihat pada Gambar 4.

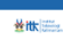

Gambar 3 Header Situs Web itk.ac.id

2. Footer, merupakan sebuah menu yang sering terdapat pada bagian bawah sebuah situs web. Fungsi dari sebuah footer adalah untuk sebagai kaki dan berisi informasi hak cipta, kepemilikan, link tambahan, sumber daya, sponsor dan kredit sebuah situs web. Adapun implementasi footer pada situs web itk.ac.id dapat dilihat pada Gambar 5.

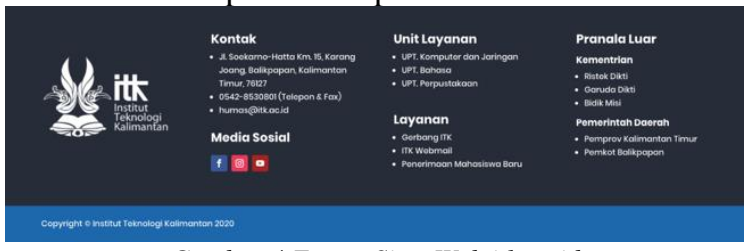

Gambar 4 Footer Situs Web itk.ac.id

4. Halaman Utama, merupakan tampilan utama dari situs web itk.ac.id, pada tampilan ini pengguna dapat melakukan interaksi melihat slider banner, melihat informasi berita terbaru, melihat informasi ringkas seputar pendidikan, kerja sama, penelitian, pengabdian masyarakat, hingga tentang ITK. Adapun implementasi halaman utama dapat dilihat pada Gambar 6.

5. Halaman Tentang ITK, berfungsi untuk memberikan informasi terkait Institut Teknologi Kalimantan. Pada halaman ini terdapat informasi tentang ITK, sambutan Rektor ITK, visi, misi, sejarah ITK, struktur organisasi, makna lambang, dan staff akademik. Adapun implementasi halaman tentang ITK dapat dilihat pada Gambar 7.

6. Halaman Jurusan, berfungsi untuk memberikan informasi terkait jurusan, program studi yang ada di kampus ITK. Pada halaman ini terdapat lima jurusan beserta empat belas program studi yang terbagi pada masing-masing jurusan. Adapun implementasi halaman jurusan dapat dilihat pada Gambar 8 .

7. Halaman Penelitian dan Pengabdian, berfungsi untuk memberikan informasi terkait aktivitas civitas ITK dalam bidang pengabdian masyarakat dan penelitian. Informasi yang dimuat pada halaman ini berupa berita acara kegiatan penelitian dan pengabdian yang telah dilaksanakan oleh civitas ITK.
Adapun implementasi halaman penelitian dan pengabdian dapat di lihat pada Gambar 9.
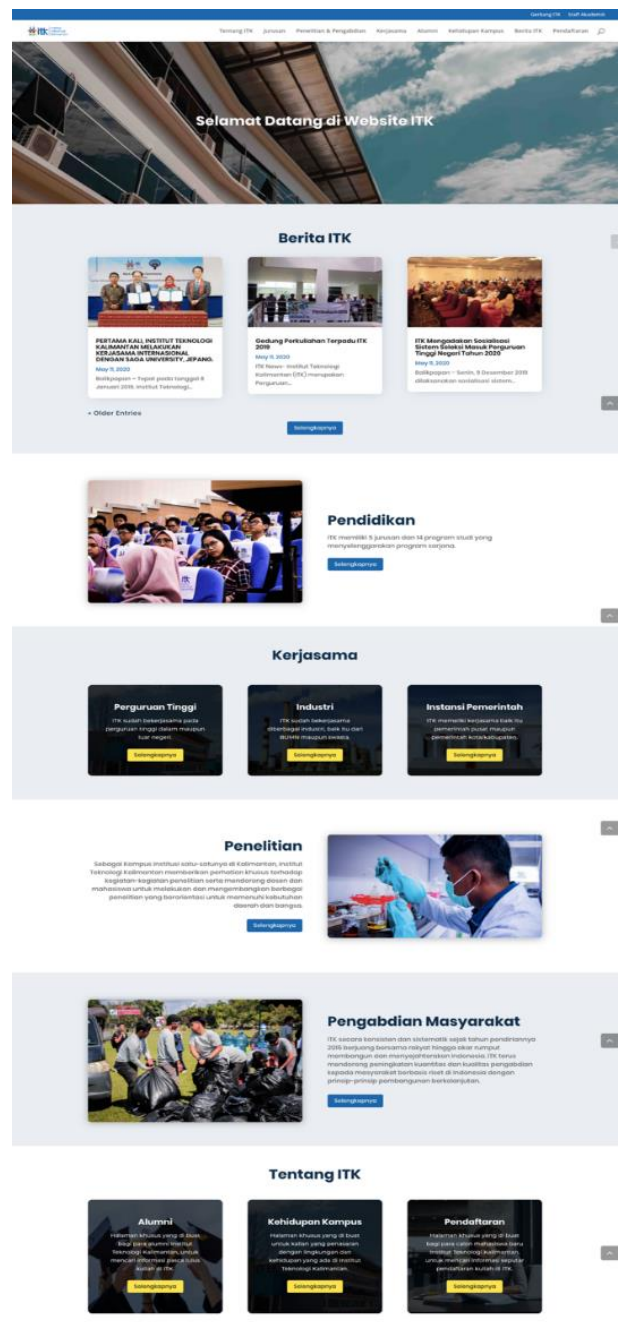

Gambar 5 Halaman Utama Situs Web itk.ac.id
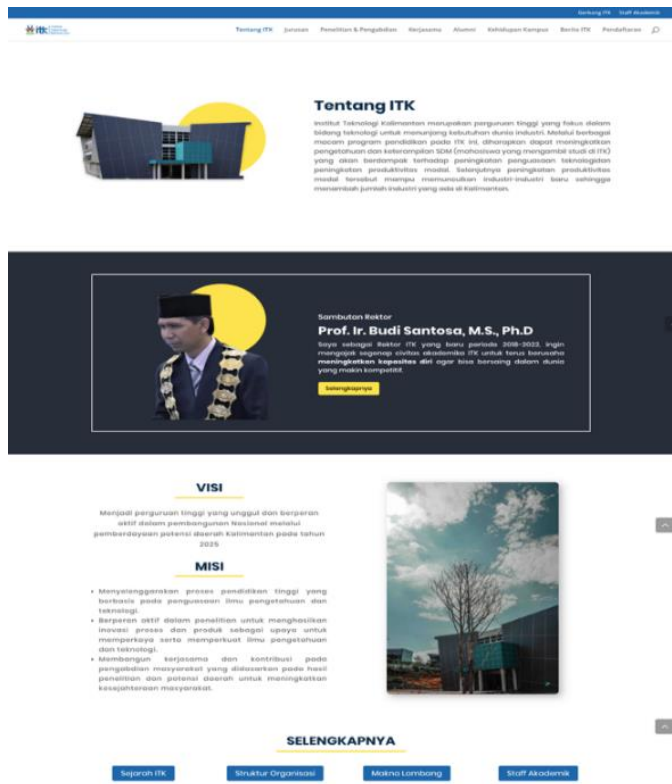

Gambar 6 Halaman Tentang ITK Situs Web itk.ac.id 

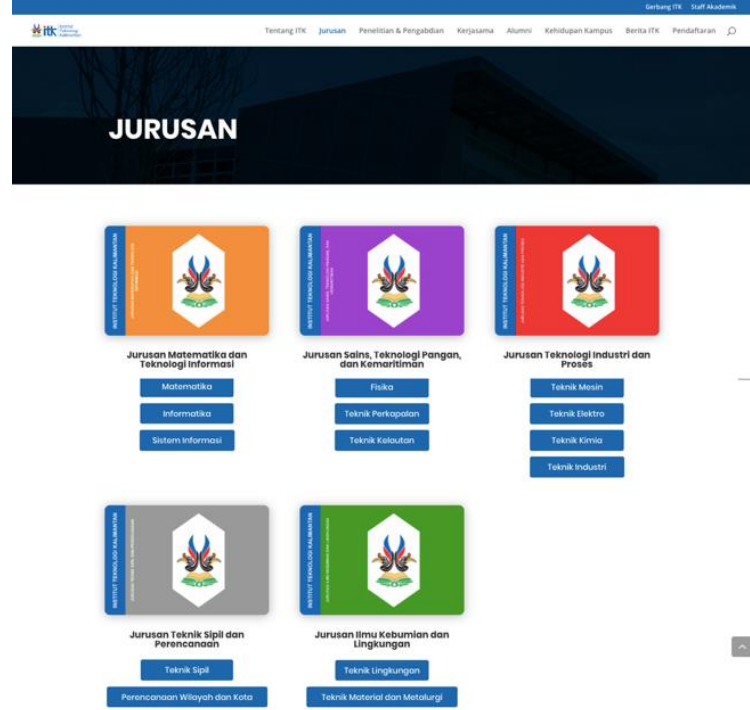

Gambar 7 Halaman Jurusan Situs Web itk.ac.id
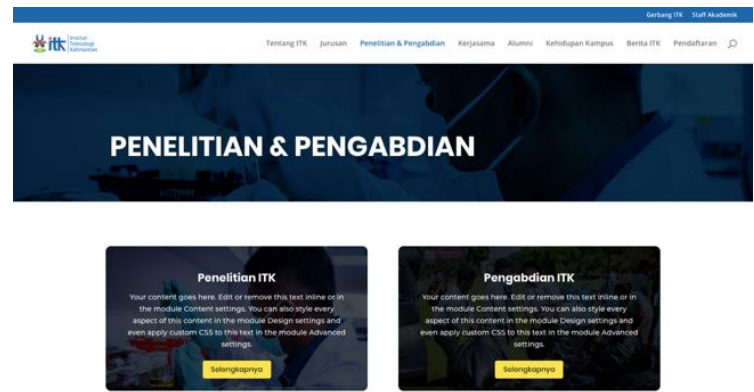

Gambar 8 Halaman Penelitian dan Pengabdian Situs Web itk.ac.id

8. Halaman Kerjasama, berfungsi untuk memberikan informasi terkait kerjasama yang telah di lakukan oleh ITK. Adapun bentuk Kerjasama yang di muat pada halaman penelitian dan pengabdian mencakup kerja sama dengan perguruan tinggi, kerjasama dengan industri, dan kerjasama dengan instansi pemerintah. Adapun implementasi halaman kerja sama dapat dilihat pada Gambar 10.
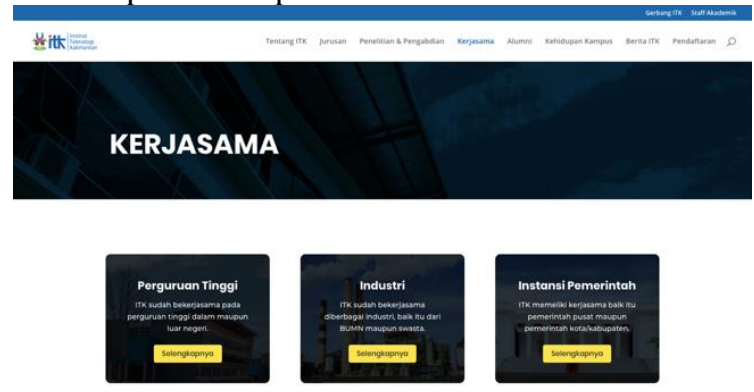

Gambar 9 Halaman Kerjasama Situs Web itk.ac.id

9. Halaman Alumni, berfungsi untuk memberikan informasi terkait alumni lulusan dari ITK. Pada halaman ini terdapat empat informasi yang di muat yaitu informasi profil alumni, data tracer alumni, bimbingan karir, dan lowongan kerja. Adapun implementasi halaman alumni dapat dilihat pada Gambar 11.
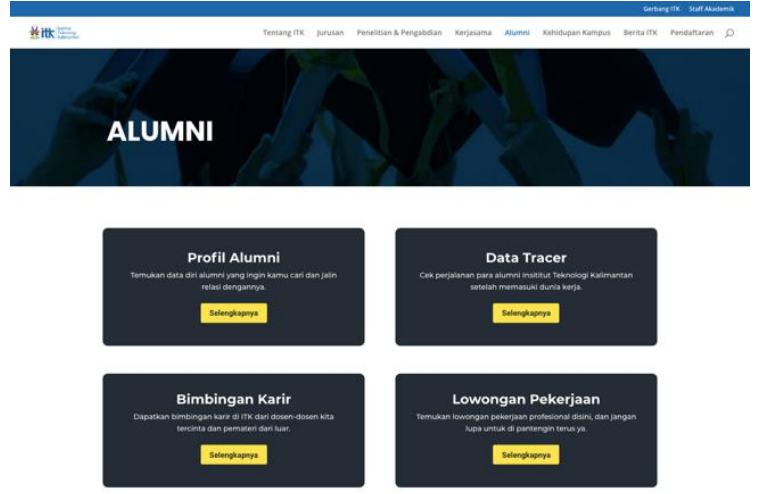

Gambar 10 Halaman Alumni Situs Web itk.ac.id

10. Halaman Kehidupan Kampus, berfungsi untuk memberikan informasi terkait segala aktivitas yang di laksanakan di kampus ITK. Pada halaman ini memuat informasi kegiatan ITK, informasi organisasi mahasiswa, organisasi kerohanian, aktivitas mahasiswa, jelajah kampus, dan lokasi kampus ITK. Adapun implementasi halaman kehidupan kampus dapat dilihat pada Gambar 12.
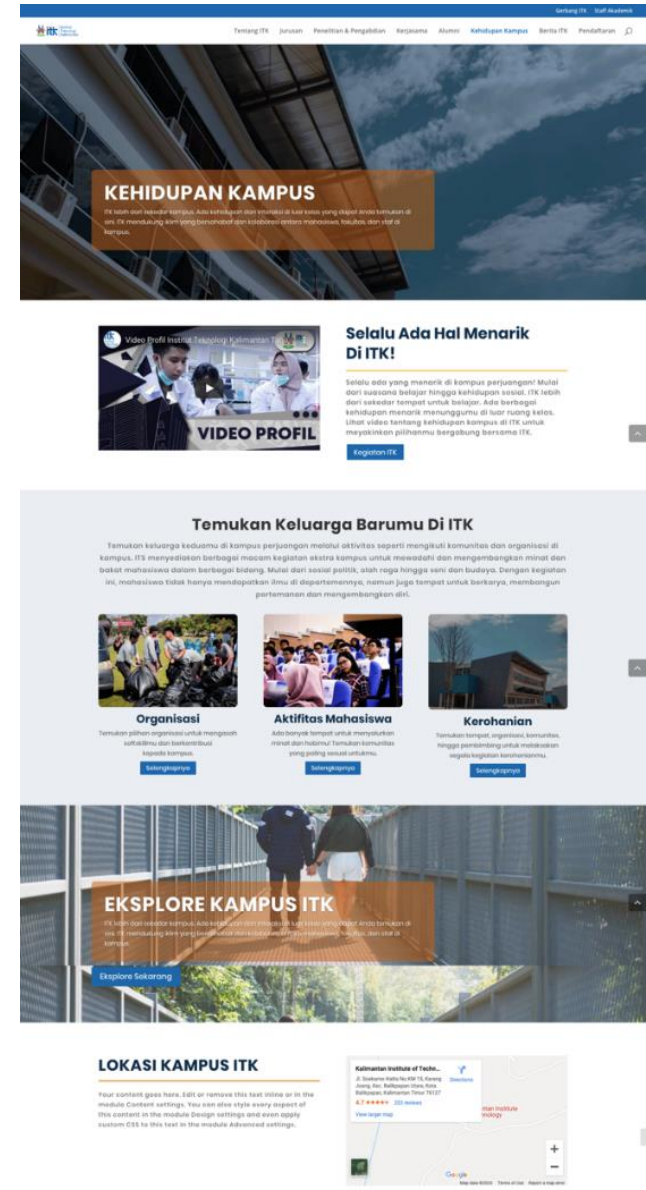

Gambar 11 Halaman Kehidupan Kampus Situs Web itk.ac.id

10. Halaman Berita ITK, berfungsi untuk menampilkan segala berita yang ada di lingkungan kampus ITK. Pada halaman ini memuat beberapa kategori yang ada di dalamnya seperti kategori penelitian, kategori pengabdian, kategori aktivitas 
mahasiswa, kategori berita ITK, kategori kegiatan ITK, dan kategori pengumuman. Adapun implementasi halaman berita ITK dapat dilihat pada Gambar 13.

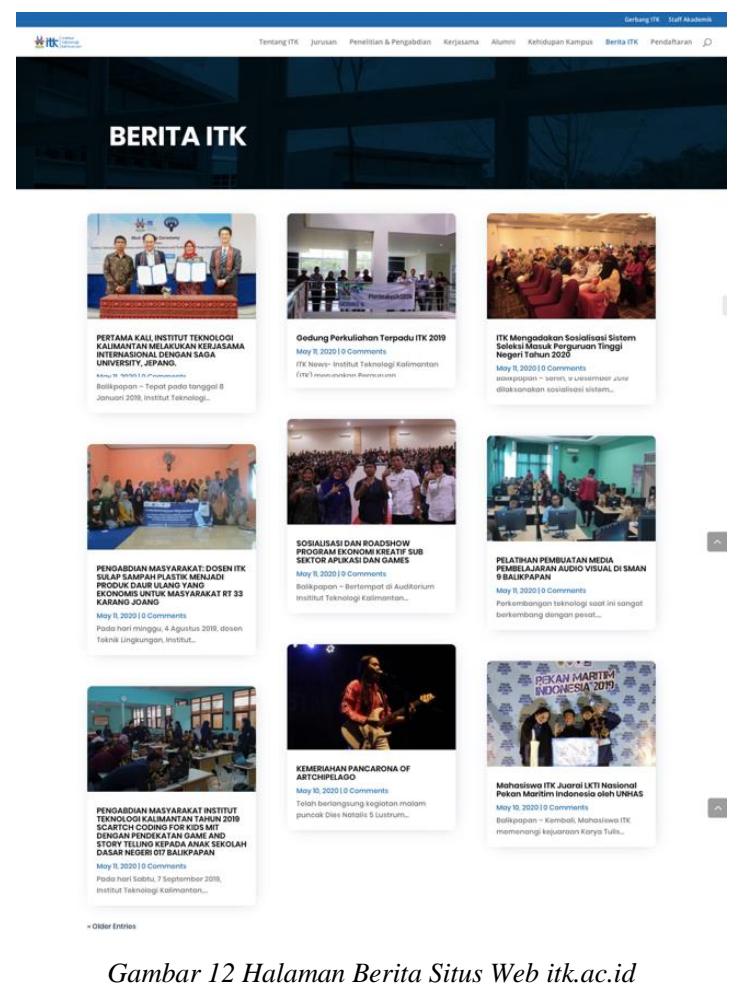

11. Halaman Pendaftaran, berfungsi untuk memberikan segala informasi terkait pendaftaran masuk ke kampus ITK. Pada halaman ini memuat informasi bagi calon mahasiswa baru, informasi SNMPTN, informasi SBMPTN, informasi UMITK, informasi beasiswa, hingga informasi biaya UKT. Adapun implementasi halaman pendaftaran dapat di lihat pada Gambar 14.

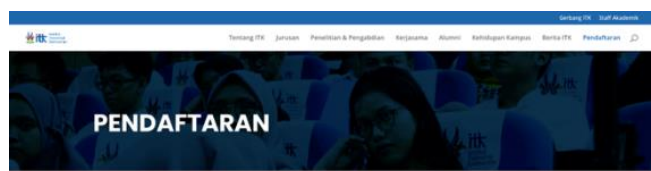

INFORMASI CALON MAHASISWA BARU

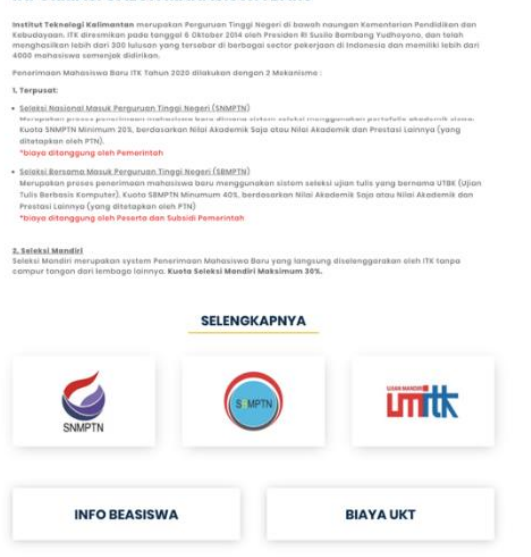

Gambar 13 Halaman Pendaftaran Situs Web itk.ac.id

\section{Evaluation}

Pada tahap ini dilakukan evaluasi kepada situs web itk.ac.id yang baru dengan menggunakan metode usability testing untuk mendapatkan data pengalaman pengguna dari penelitian evaluasi dan redesign website ITK. Dengan dilakukannya evaluasi usability testing kepada tujuh pengguna yang terdiri dari lima laki-laki dan dua perempuan. Dari hasil evaluasi usability testing didapatkan data keberhasilan pengujian, durasi waktu yang dibutuhkan, hingga jumlah klik dan langkah. Berikut merupakan hasil perhitungan usability pada kriteria Learnability, Efficiency, Memorability, dan Error.

\section{Learnability}

Setelah mendapatkan data waktu pengerjaan dari setiap partisipan pada pengujian situs web itk.ac.id yang baru dan lama, selanjutnya tahap perhitungan rasio learnability antara situs web ITK lama dan baru dengan menggunakan Persamaan (1).

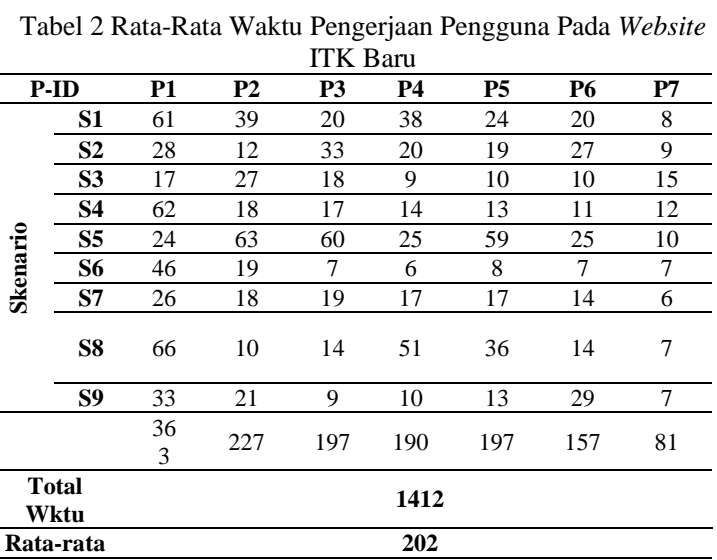

Tabel 3 Rata-Rata Waktu Pengerjaan Pengguna Pada Website

\begin{tabular}{|c|c|c|c|c|c|c|c|c|}
\hline \multicolumn{2}{|c|}{ P-ID } & P1 & $\mathbf{P 2}$ & P3 & P4 & P5 & P6 & P7 \\
\hline \multirow{10}{*}{ 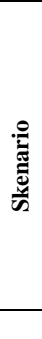 } & S1 & 19 & 23 & 9 & 7 & 47 & 12 & 24 \\
\hline & S2 & 33 & 68 & 61 & 19 & 151 & 108 & 94 \\
\hline & $\mathbf{S 3}$ & 21 & 37 & 19 & 16 & 40 & 7 & 68 \\
\hline & S4 & 84 & 36 & 21 & 30 & 26 & 41 & 56 \\
\hline & S5 & 48 & 48 & 23 & 16 & 13 & 29 & 105 \\
\hline & S6 & 24 & 16 & 24 & 13 & 21 & 9 & 24 \\
\hline & S7 & 35 & 14 & 22 & 15 & 18 & 12 & 45 \\
\hline & S8 & 30 & 37 & 17 & 21 & 17 & 40 & 30 \\
\hline & S9 & 140 & 49 & 16 & 21 & 20 & 20 & 41 \\
\hline & & 434 & 328 & 212 & 158 & 353 & 278 & 478 \\
\hline \multicolumn{2}{|c|}{$\begin{array}{l}\text { Total } \\
\text { Wktu }\end{array}$} & \multicolumn{7}{|c|}{2250} \\
\hline \multicolumn{2}{|c|}{ Rata-rata } & \multicolumn{7}{|c|}{321.42} \\
\hline
\end{tabular}

Setelah mendapatkan data waktu pengerjaan dari setiap partisipan pada pengujian pertama dan kedua selanjutnya akan didapatkan rasio learnability dengan persamaan (1)

$$
\begin{aligned}
& \frac{\text { rata }- \text { rata waktu pengujian web ITK lama }}{\text { rata - rata waktu pengujian web ITK baru }} \\
& =\frac{321.42}{202}=\mathbf{2}
\end{aligned}
$$

Dalam hal ini, hasil learnability situs web itk.ac.id sebesar 2 yang artinya pengguna pada situs web 
itk.ac.id yang baru mengalami percepatan waktu sekitar 2x lebih cepat jika dibandingkan dengan pengujian pada situs web itk.ac.id yang lama.

\section{Efficiency}

Dalam kriteria efficiency diukur berdasarkan waktu yang berhasil diselesaikan oleh partisipan dengan nilai kesuksesan skenario di kerjakan oleh partisipan. Adapun data kriteria efficiency ditunjukkan pada Tabel 4.

\begin{tabular}{|c|c|c|c|c|c|c|c|c|}
\hline \multicolumn{2}{|c|}{ P-ID } & P1 & $\mathrm{P} 2$ & P3 & P4 & P5 & P6 & P7 \\
\hline \multirow{10}{*}{ 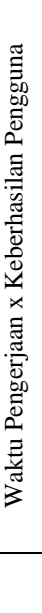 } & S1 & $\begin{array}{c}61 \\
(0.5) \\
\end{array}$ & $\begin{array}{l}39 \\
(1\end{array}$ & $\begin{array}{l}20 \\
(1) \\
\end{array}$ & $\begin{array}{c}38 \\
(0.5) \\
\end{array}$ & $\begin{array}{l}24 \\
(1)\end{array}$ & $\begin{array}{l}20 \\
(1)\end{array}$ & $\begin{array}{c}8 \\
(1) \\
\end{array}$ \\
\hline & $\mathrm{S} 2$ & $\begin{array}{l}28 \\
(1) \\
\end{array}$ & $\begin{array}{l}12 \\
(1) \\
\end{array}$ & $\begin{array}{l}33 \\
(1) \\
\end{array}$ & $\begin{array}{l}20 \\
(1) \\
\end{array}$ & $\begin{array}{l}19 \\
(1) \\
\end{array}$ & $\begin{array}{l}27 \\
(1) \\
\end{array}$ & $\begin{array}{c}9 \\
(1) \\
\end{array}$ \\
\hline & S3 & $\begin{array}{l}17 \\
(1) \\
\end{array}$ & $\begin{array}{l}27 \\
(1) \\
\end{array}$ & $\begin{array}{l}18 \\
(1) \\
\end{array}$ & $\begin{array}{c}9 \\
(1) \\
\end{array}$ & $\begin{array}{l}10 \\
(1) \\
\end{array}$ & $\begin{array}{l}10 \\
(1) \\
\end{array}$ & $\begin{array}{l}15 \\
(1) \\
\end{array}$ \\
\hline & S4 & $\begin{array}{l}62 \\
\text { (1) }\end{array}$ & $\begin{array}{l}18 \\
(1\end{array}$ & $\begin{array}{l}17 \\
(1)\end{array}$ & $\begin{array}{l}14 \\
(1)\end{array}$ & $\begin{array}{l}13 \\
(1)\end{array}$ & $\begin{array}{l}11 \\
(1)\end{array}$ & $\begin{array}{l}12 \\
\text { (1) }\end{array}$ \\
\hline & S5 & $\begin{array}{l}24 \\
(1) \\
\end{array}$ & $\begin{array}{l}63 \\
(1) \\
\end{array}$ & $\begin{array}{l}60 \\
(1) \\
\end{array}$ & $\begin{array}{l}25 \\
(1)\end{array}$ & $\begin{array}{c}59 \\
(0.5) \\
\end{array}$ & $\begin{array}{l}25 \\
(1) \\
\end{array}$ & $\begin{array}{l}10 \\
(1) \\
\end{array}$ \\
\hline & S6 & $\begin{array}{l}46 \\
\text { (1) }\end{array}$ & $\begin{array}{l}19 \\
(1)\end{array}$ & $\begin{array}{c}7 \\
(1)\end{array}$ & $\begin{array}{c}6 \\
\text { (1) }\end{array}$ & $\begin{array}{c}8 \\
(1)\end{array}$ & $\begin{array}{c}7 \\
(1)\end{array}$ & $\begin{array}{c}7 \\
\text { (1) }\end{array}$ \\
\hline & S7 & $\begin{array}{l}26 \\
(1) \\
\end{array}$ & $\begin{array}{l}18 \\
(1)\end{array}$ & $\begin{array}{l}19 \\
(1)\end{array}$ & $\begin{array}{l}17 \\
(1)\end{array}$ & $\begin{array}{l}15 \\
(1) \\
\end{array}$ & $\begin{array}{l}14 \\
(1)\end{array}$ & $\begin{array}{c}6 \\
\text { (1) }\end{array}$ \\
\hline & S8 & $\begin{array}{l}66 \\
(1)\end{array}$ & $\begin{array}{l}10 \\
(1)\end{array}$ & $\begin{array}{l}14 \\
(1)\end{array}$ & $\begin{array}{l}51 \\
(1)\end{array}$ & $\begin{array}{l}36 \\
(1)\end{array}$ & $\begin{array}{l}14 \\
(1)\end{array}$ & $\begin{array}{c}7 \\
\text { (1) }\end{array}$ \\
\hline & S9 & $\begin{array}{l}33 \\
(1) \\
\end{array}$ & $\begin{array}{l}21 \\
(1)\end{array}$ & $\begin{array}{c}9 \\
(1)\end{array}$ & $\begin{array}{l}10 \\
(1)\end{array}$ & $\begin{array}{l}13 \\
(1) \\
\end{array}$ & $\begin{array}{l}29 \\
(1)\end{array}$ & $\begin{array}{c}7 \\
(1) \\
\end{array}$ \\
\hline & & 332.5 & 227 & 197 & 171 & 167.5 & 157 & 81 \\
\hline \multicolumn{2}{|c|}{ Total } & \multicolumn{7}{|c|}{1333} \\
\hline
\end{tabular}

Setelah mendapatkan data waktu dan kesuksesan pengujian situs web itk.ac.id yang lama dan baru, selanjutnya akan didapatkan nilai efisiensi dari situs web itk.ac.id dengan menggunakan persamaan (2).

$$
\begin{aligned}
& \text { Time Based Efficiency }=\frac{\sum_{J}^{R} \sum_{i=1}^{N} \frac{N i j}{t i j}}{N R} \times 100 \% \\
& =\frac{1333}{1412} \times 100 \%=\mathbf{9 4 . 4 0} \%
\end{aligned}
$$

Hasil dari pengujian kriteria efficiency adalah sebesar $94.40 \%$ yang artinya dalam situs web itk.ac.id yang baru bisa digunakan oleh pengguna untuk mencapai tujuannya sebesar $94.40 \%$.

\section{Memorability}

Berdasarkan data rata-rata jumlah langkah dan klik peserta saat melaksanakan pengujian skenario, berikutnya dilakukan pengukuran memorability menggunakan data pada Tabel 5 dengan cara mengamati jumlah klik dan jumlah langkah yang telah dilakukan oleh partisipan selama proses pengujian skenario berlangsung yang ditunjukkan pada Gambar 15.

\begin{tabular}{ccccc}
\multicolumn{4}{c}{ Tabel } & \multicolumn{3}{c}{ Rata-Rata Jumlah Langkah dan Klik Pada Website ITK } \\
\hline P-ID & $\begin{array}{c}\text { Pengujian Website } \text { ITK } \\
\text { Lama }\end{array}$ & $\begin{array}{c}\text { Pengujian Website } \\
\text { ITK }\end{array}$ \\
\cline { 2 - 5 } & $\begin{array}{c}\text { Jumlah } \\
\text { Langkah }\end{array}$ & $\begin{array}{c}\text { Jumlah } \\
\text { Klik }\end{array}$ & $\begin{array}{c}\text { Jumlah } \\
\text { langkah }\end{array}$ & $\begin{array}{c}\text { Jumlah } \\
\text { Klik }\end{array}$ \\
\hline P1 & 2 & 3 & 2 & 3 \\
\hline P2 & 2 & 2 & 2 & 2 \\
\hline P3 & 1 & 2 & 2 & 2 \\
\hline P4 & 1 & 2 & 2 & 2 \\
\hline P5 & 2 & 2 & 2 & 2 \\
\hline P6 & 2 & 2 & 2 & 2 \\
\hline P7 & 4 & 5 & 2 & $\mathbf{2 . 1 4}$ \\
\hline Rata & $\mathbf{2}$ & $\mathbf{3}$ & $\mathbf{2}$ & \\
-rata & & & & 2 \\
\hline
\end{tabular}

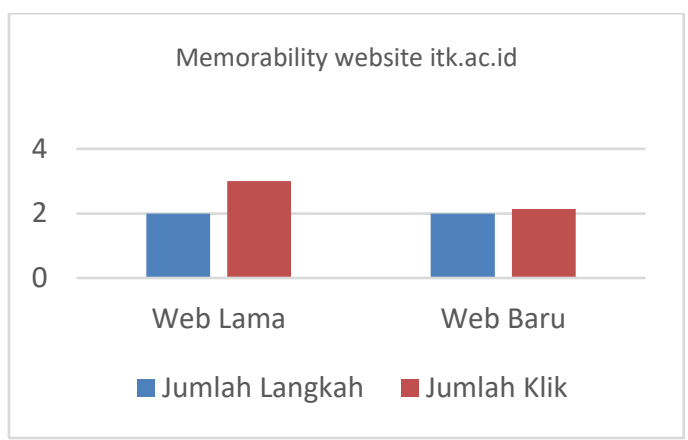

Gambar 14 Perbandingan Rata-rata Jumlah Klik dan Langkah

Pada diagram di atas menunjukkan bahwa hasil ratarata dari langkah dan jumlah klik pada pengguna tidak terlalu jauh berbeda nilainya, hanya saja terjadi penurunan jumlah klik pada saat penguji skenario menggunakan situs web itk.ac.id yang baru. Dari pengujian skenario situs web itk.ac.id yang lama didapatkan data rata-rata jumlah klik sebanyak 3 dan rata-rata jumlah langkah sebanyak 2 , lalu turun pada pengujian dengan situs web yang baru menjadi 2.14 pada rata-rata jumlah klik dan rata-rata jumlah langkah sebanyak 2 langkah pada situs web itk.ac.id yang baru.

\section{Error}

Pada kriteria error dilakukan analisis terkait jumlah error yang terjadi pada saat partisipan melaksanakan pengujian skenario usability testing. Setiap ditemukan kesalahan dalam menyelesaikan progres akan dihitung salah, apabila partisipan dapat mengerjakan skenario yang diberikan dengan benar maka akan dihitung benar. Setiap langkah yang dilakukan akan diakumulasikan dengan nilai (B) untuk benar dan (S) untuk salah.

Tabel 6 merupakan data persentase tingkat kesalahan yang dapat terjadi pada situs web itk.ac.id yang baru, yang di mana data tingkat terjadinya kesalahan pada situs web itk.ac.id yang baru ialah sebesar $1.61 \%$. Nilai tersebut cenderung kecil dan termasuk kategori rendah sehingga dapat disimpulkan bahwa tingkat error yang terjadi pada situs web itk.ac.id yang baru sangat rendah. 
Tabel 6 Jumlah Kesalahan Pada Kriteria Error

\begin{tabular}{|c|c|c|c|c|c|c|c|c|}
\hline \multicolumn{2}{|c|}{ P-ID } & P1 & P2 & P3 & P4 & P5 & P6 & P7 \\
\hline \multirow{2}{*}{ S1 } & $\mathrm{B}$ & 2 & 3 & 3 & 2 & 3 & 3 & 3 \\
\hline & $\mathrm{S}$ & 1 & 0 & 0 & 1 & 0 & 0 & 0 \\
\hline \multirow{2}{*}{ S2 } & B & 4 & 4 & 4 & 4 & 4 & 4 & 4 \\
\hline & $\mathrm{S}$ & 0 & 0 & 0 & 0 & 0 & 0 & 0 \\
\hline \multirow{2}{*}{ S3 } & B & 2 & 2 & 2 & 2 & 2 & 2 & 2 \\
\hline & $\mathrm{S}$ & 0 & 0 & 0 & 0 & 0 & 0 & 0 \\
\hline \multirow{2}{*}{ S4 } & B & 3 & 3 & 3 & 3 & 3 & 3 & 3 \\
\hline & $\mathrm{S}$ & 0 & 0 & 0 & 0 & 0 & 0 & 0 \\
\hline \multirow{2}{*}{ S5 } & B & 3 & 3 & 3 & 3 & 2 & 3 & 3 \\
\hline & $\mathrm{S}$ & 0 & 0 & 0 & 0 & 1 & 0 & 0 \\
\hline \multirow{2}{*}{ S6 } & B & 4 & 4 & 4 & 4 & 4 & 4 & 4 \\
\hline & $\mathrm{S}$ & 0 & 0 & 0 & 0 & 0 & 0 & 0 \\
\hline \multirow{2}{*}{ S7 } & B & 3 & 3 & 3 & 3 & 3 & 3 & 3 \\
\hline & $\mathrm{S}$ & 0 & 0 & 0 & 0 & 0 & 0 & 0 \\
\hline \multirow{2}{*}{ S8 } & $\mathrm{B}$ & 3 & 3 & 3 & 3 & 3 & 3 & 3 \\
\hline & $\mathrm{S}$ & 0 & 0 & 0 & 0 & 0 & 0 & 0 \\
\hline \multirow{2}{*}{ S9 } & B & 3 & 3 & 3 & 3 & 3 & 3 & 3 \\
\hline & $\mathrm{S}$ & 0 & 0 & 0 & 0 & 0 & 0 & 0 \\
\hline \multicolumn{2}{|c|}{ Total Salah } & 1 & 0 & 0 & 1 & 1 & 0 & 0 \\
\hline \multicolumn{2}{|c|}{$\begin{array}{c}\text { Tingkat t } \\
\text { error }\end{array}$} & & & \multicolumn{4}{|c|}{$x 100 \%=1.61 \%$} & \\
\hline
\end{tabular}

\section{KESIMPULAN DAN SARAN}

Dengan dilakukannya perbaikan situs web ITK menggunakan metode User Experience Lifecycle Template ini dapat menghasilkan situs web yang berfokus pada aspek usability. Hal ini ditunjukkan oleh hasil analisis data evaluasi usability pada empat aspek yaitu learnability, afficiency, memorability dan error. Pada aspek learnability pengguna situs web itk.ac.id yang baru mengalami percepatan waktu sekitar 2x lebih cepat jika dibandingkan dengan pengujian pada situs web itk.ac.id yang lama. Pada aspek efficiency, situs web itk.ac.id yang baru bisa digunakan oleh pengguna untuk mencapai tujuannya sebesar $94.40 \%$. Pada aspek memorability, rata-rata jumlah klik pada situs web itk.ac.id yang lama sebanyak 3 dan rata-rata jumlah langkah sebanyak 2, lalu turun pada pengujian dengan situs web yang baru menjadi 2.14 pada rata-rata jumlah klik dan rata-rata jumlah langkah sebanyak 2. Pada aspek error, data tingkat terjadinya kesalahan pada situs web itk.ac.id yang baru ialah sebesar $1.61 \%$ tergolong kategori rendah. Untuk pengembangan selanjutnya dapat melakukan pengambilan data keseluruhan internal Institut Teknologi Kalimantan atau pengambilan data dari sudut pandang eksternal Institut Teknologi Kalimantan. Dalam meningkatkan aspek usability tahap selanjutnya pengembang dapat menerapkan metode User Experience Lifecycle Template kembali namun lebih di fokuskan kepada bagian desain interaksi pengguna agar lebih meningkatkan aspek satisfaction pada situs web ITK, atau pengembang juga dapat menggunakan metode Simple Interaction Design Model atau metode User Centered Design sebagai metodologi utama. Dalam meningkatkan aspek usability tahap selanjutnya pengembang dapat memulai dari tahap evaluasi dengan menggunakan metode System Usability Scale (SUS) untuk mengetahui tingkat kepuasan atau satisfaction pengguna situs web itk.ac.id.

\section{DAFTAR PUSTAKA}

ARIKUNTO, S., 2006. Prosedur penelitian : suatu pendekatan praktek. Jakarta: Rineka Cipta.

BANK, C., 2014. Web UI Design Best Practices. California, USA: UXPin.

GOODMAN, E., KUNIAVSKY, M. \& MOED, A., 2012. Observing the User Experience. 2nd penyunt. USA: Elsevier,Inc.

MORVILLE, P. \& ROSENFELD, L., 2007. Information Architecture for the World Wide Web. 3rd penyunt. USA: O'Reilly Media, Inc.

NASUTION, S., 2006. Metode Penelitian Naturalistik-kualittaif. Bandung: Tarsito.

NIELSEN, J., 1995. 10 Usability Heuristics for User Interface Design.. s.l.:s.n.

POLANCIK, G., 2009. Empirical Research Method Poster.

PRAMONO, W. A., AZ-ZAHRA, H. M. \& ROKHMAWATI, R. I., 2019. Evaluasi Usability pada Aplikasi MyTelkomsel dengan Menggunakan Metode Usability Testing. Volume 3.

PREECE, J., Y VONNE, R. \& SHARP, H., 2002. Interaction design : beyond humancomputer interaction. 4th penyunt. New York: Jhon Wiley \& Sons, Inc.

REX, H. \& PARDHA, P., 2012. The UX Book: Process and guidelines for ensuring a quality user experience. USA: Morgan Kaufmann.

SUGIYONO, P. D., 2011. Metode Penelitian Kuantitatif, Kualitatif, dan $R \& D$. XIII penyunt. Bandung: Alfabeta.

SULISTIYONO, M., 2017. EVALUASI HEURISTIC SISTEM INFORMASI PELAPORAN KERUSAKAN LABORATORIUM UNIVERSITAS AMIKOM YOGYAKARTA. DATA MANAJEMEN DAN TEKNOLOGI INFORMASI, Volume 18, pp. 37-43.

TOMLIN, W. C., 2018. UX Optimization: Combining Behavioral UX and Usability Testing Data to. Texas: Apress Media LLC.

YUMARLIN, M., 2016. Evaluasi Penggunaan Website Universitas Janabadra dengan Menggunakan Metode Usability Testing. Jurnal Informasi Interaktif, Volume 1, pp. 3543. 
Halaman ini sengaja dikosongkan 